\title{
Visual symptoms and control of the Red Palm Weevil (Rhynchophorus ferrugineus) in the Gaza Strip, Palestine
}

\author{
ABDEL FATTAH N. ABD RABOU ${ }^{\natural}$, EQBAL S. RADWAN \\ Department of Biology, Faculty of Science, Islamic University of Gaza, P.O.Box 108, Gaza Strip, Palestine. Tel.: (+970-8-2860-700, Fax.: +970-8-2860- \\ 800), "email: arabou@iugaza.edu.ps
}

Manuscript received: 19 June 2017. Revision accepted: 31 August 2017.

\begin{abstract}
Abd Rabou AN, Radwan ES. 2017. Visual symptoms and control of the Red Palm Weevil (Rhynchophorus ferrugineus) in the Gaza Strip, Palestine. Nusantara Bioscience 9: 322-329. The Red Palm Weevil - RPW (Rhynchophorus ferrugineus Olivier) (Coleoptera: Curculionidae) has recently become one of the most destructive pests of Date Palms in the Gaza Strip and the Middle East. It is a serious pest threatening the Date Palm health and production, with the larva is the most destructive stage. The current study aims at introducing the visual symptoms and control techniques of the RPW in the Gaza Strip, Palestine. Field surveys and institutional visits were applied to fulfill the purpose of the study. The current study documented that first local infestation of Date Palm trees with the RPW was discovered in late 2011. The introduction of infected offshoots from Egypt through earth tunnel trade and the ability of the adult RPW to fly long distance and cross borders seem to be main causes of the local infestations with the pest. Different control techniques have been adopted by the responsible parties to combat the RPW; with the integrated pest management (IPM) program was tracked and respected. Finally, the study recommends the cooperation of different parties and authorities to adopt appropriate policies to eliminate the RPW and to support farmers with the necessary pesticides and equipment to control this painful pest.
\end{abstract}

Keywords: Red palm weevil, date palm, control, IPM, Gaza Strip, Palestine

\section{INTRODUCTION}

Date Palm (Phoenix dactylifera) is the most important fruit tree of arid, tropical and sub-tropical regions of the world. It is a holy tree because of its commercial, nutritional, environmental, social, health and religious values (Chao and Krueger 2007). The Date Palm is commonly attacked by different pests, but in the recent years the Red Palm Weevil - RPW (Rhynchophorus ferrugineus, Olivier) (Coleoptera: Curculionidae), became one of the most dangerous threats to the Date Palm trees in most parts of the world including the U.S.A. (Nisson et al. 2010). The spread of RPW comes mainly from transporting of infested Date Palm trees and offshoots from infected regions to other places (Ferry and Gommez 2002). Nowadays, the date palm crop is under a real threat in the Arab countries including the Palestinian Territories.

The RPW is known to cause significant ecological and economic damages to farmers (Hoddel et al. 2015). It is responsible for the death of a large number of Date Palm trees and consequent yield losses (Vidyasagar and Aldosari 2011; Vidyasagar et al. 2016). According to Abraham et al. (1998), RPW mostly attacks young Date Palm trees under the age of 20 years. The length of the RPW life cycle varies depending on the environmental and geographical conditions (Murphy and Briscoe 1999). This pest hide and remains inside the palm during larval development and makes tunnels and pupates. Because of the concealed nature of RPW larvae (The main stage cause the injury), effective methods to control this pest have been difficult to develop.
The existing methods for managing and controlling the RPW depend on its stage of attack (Al-Saqer and Hassan 2011). The Integrated Pest Management (IPM) program is most successful in controlling and managing this serious pest. It ensures a regular monitoring and treating of infested Date Palm trees. Other actions are included and respected such as the detection of the RPW at early stage, trapping of the adult insects, treatment of wounds, eradication of infested trees, and education of farmers on the best management ways to deal with the RPW (Al-Saqer and Hassan 2011; Faleiro et al. 2012; Al-Dosary et al. 2016).

Multi-purpose surveys regarding the RPW were carried out in different countries worldwide. Abe et al. (2009) highlighted the life history of the RPW in 17 infested Phoenix canariensis trees in southern Japan. In developing countries, many researchers focused on the ecological aspects and pattern of RPW infestation in Date Palm orchards in addition to the methods engaged in the RPW control and management (Azam et al. 2001; Kaakeh et al. 2001; Bertone et al. 2010; Abdel-Wahed et al. 2014; Mazza et al. 2014).

In the Palestinian Territories, many studies have been conducted concerning the status and perspective of the Date Palm tree and its pests including the RPW (AbuQaoud 2015; Al-Agha 2016; Radwan 2017; Abd Rabou and Radwan 2017). Abu-Qaoud (2015) pointed out that the productivity of Date Palms has declined as a result of pests including the RPW and the death of a great number of Date Palm trees infested. Ferry and Gomez (2002) mentioned that an early detection of the pest in the Palestinian Territories resulted very quickly in the establishment of an 
IPM program. In the Gaza Strip, work on the RPW is restricted to a few studies. Al-Jaghoub et al. (2003), Ministry of Agriculture - MOA (2011 and 2012), Earth and Human Center for Research and Study - EHCRS (2011), and Al-Ahlyah Association for the Development of Date Palm - ASDPD (2012) described the nature of the RPW, reasons and symptoms of infection in addition to the methods of early detection and control levels.

Moreover, El-Hindi (2017) and El Kichaoui et al. (2017) revealed that the use of Metarhizium anisopliae and Beauveria bassiana fungi can be useful as a preventive and curative tool for the protection of Date Palm tree against the RPW in the Gaza Strip. Because of the critical situation dictated by the RPW on Date Palm sector locally, and the real shortage of studies treating this painful pest, the current study comes to introduce descriptive data on the occurrence of the RPW (Rhynchophorus ferrugineus, Olivier) in the Gaza Strip in terms of infestation and control techniques adopted by the responsible parties. This study tries to raise the Gazans' awareness towards the RPW that threatens the Date Palm as a strategic and resistant crop in the Gaza Strip.

\section{MATERIALS AND METHODS}

\section{Study area}

The Gaza Strip (Figure 1) is very populated (about 2.0 million) with an area of $365 \mathrm{~km}^{2}$. It lies on the eastern coast of the Mediterranean Sea that borders Egypt on the southwest for $11 \mathrm{~km}$ and the Occupied Palestinian Territories on the east and north along a $51 \mathrm{~km}$ border (PCBS, 2016). The Gaza Strip has the semi-arid Mediterranean climate. The average daily mean temperature ranges from $25^{\circ} \mathrm{C}$ in summer to $13^{\circ} \mathrm{C}$ in winter. The daily relative humidity fluctuates between $60 \%$ to $85 \%$ throughout the year depending on seasons (UNEP 2003).

\section{Site and institutional visits}

During the course of the present study, frequent visits were carried out to different Date Palm orchards in order to investigate the current status of the RPW and its control and management methods in the Gaza Strip. Meetings and discussions with farmers and owners were of utmost priority to fill the gaps needed in data collection. Moreover, vital visits were carried out to the MOA, EHCRS, ASDPD and the Palestinian Al-Nakheel Association for Progress and Development (PNAPD). A set of close and open ended questions were developed and used during the structured and semi-structured interviews conducted.

\section{Photography and data analysis}

For documentary purposes, a digital camera was used to take photos covering the stages of RPW infestation and control in the Gaza Strip. The data collected throughout the course of the study were plotted using Microsoft Excel program 2010.

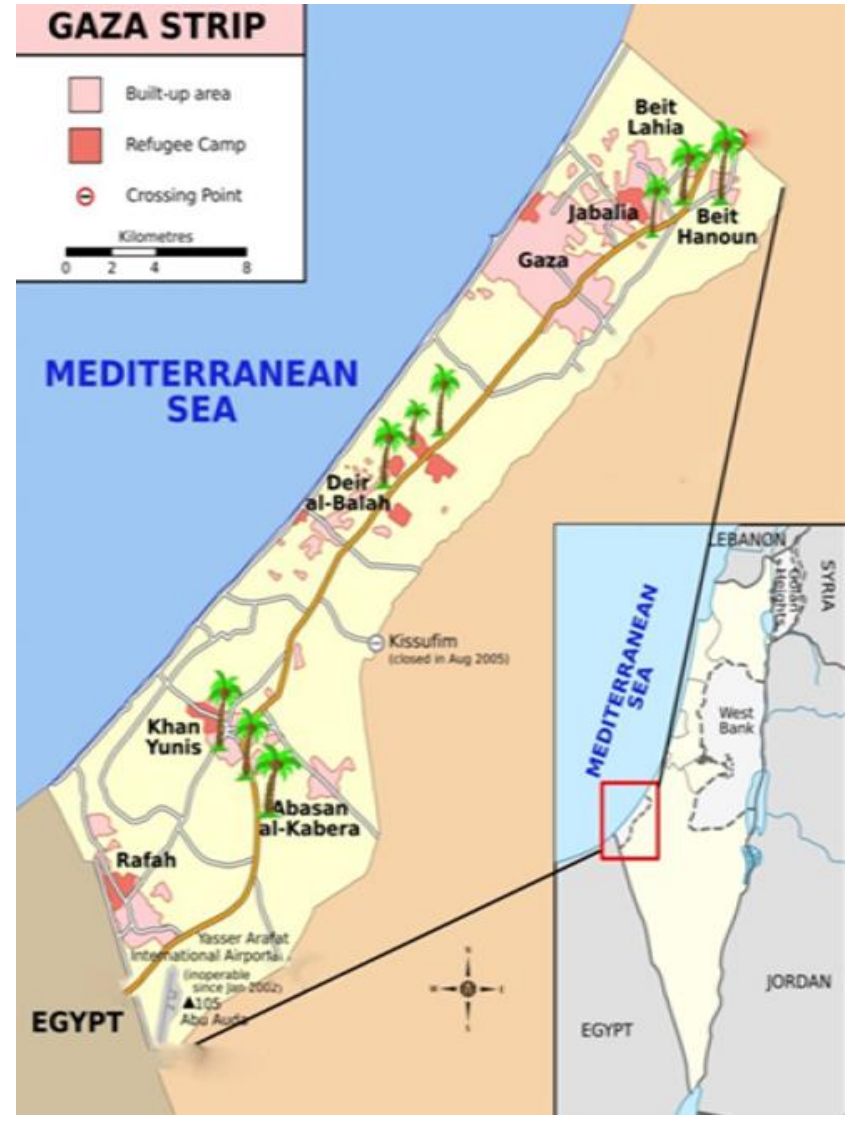

Figure 1. The geographic location of the Gaza Strip, Palestine

\section{RESULTS AND DISCUSSION}

\section{Discovery and origin of the RPW pest}

First detection of RPW was noticed in September 2011 in a Date Palm nursery in the Middle Governorate of the Gaza Strip. It has been assumed by the farmers and the specialized authorities that the origin of RPW was the infested Date Palms of the Egyptian area bordering Gaza Strip, and the introduction of infested offshoots from Egypt through the earth tunnel trade. Many zones in the Date Palm are usually infested by the RPW. These include the aerial offshoots and apical region, offshoot near to the soil surface, zone infected with Palm Stalk Borer and modern wounds, holes, and tunnels caused boring fauna. With regard to the reasons promoting the injury of Date Palms with RPW, they were numerous as follows: (i) Removal of offshoots in periods of insect activity. (ii) Over-pruning of Date Palm trees (iii) Ignorance of wound treatment. (iv) Prior infection with Date Palm borers. (v) Wounds, holes, and tunnels caused by boring fauna. It is commonly known that the holes made by the Fruit Stalk Borer may provide appropriate places for the RPW to lay its eggs. (vi) The use of flood irrigation system. 


\section{Symptoms of infection with RPW}

There were many symptoms noted and commonly photographed in the infested Date Palm orchards visited in the southern parts of the Gaza Strip as follows: (i) The presence of tunnels and cavities on the trunk or at the bases of leaf petiole (Figure 2.A). (ii) Hearing of gnawing sounds due to feeding by grubs. (iii) Oozing out of thick brown fluid from the tunnels (Figure 2.B). (iv) The presence of chewed plant tissues with a typical fermented odor in and around the openings of the tunnels (Figure 2.C and D). (v) Breaking of the trunk or toppling of the crown in case of severe and prolonged infestation (Figure 2.E). (vi) Drying and/or death of Date Palm offshoots in case of severe injuries (Figure 2.F). (vii) Drying of Date Palm fruits and sometimes the death of leaves in the heart of trees (Figure 2.G). (viii) The presence of any of the RPW phases (Figure 2.H).

\section{The different stages of RPW noted in Date Palm orchards}

During field visits conducted to Date Palm orchards, all the four stages of the RPW were monitored and photographed inside the infested Date Palm trees as follows: (i) Egg stage: The eggs (Figure 3.A) are usually found hidden inside the palm. The female RPW deposits its eggs inside the wounds of the leaves and trunks, cavities, or the roots of offshoots. (ii) Larval stage: The larva (Figure 3.B) is the most destructive stage to Date Palms when it feeds on the soft succulent tissues. When feeding by boring inside the trunk, it eliminates stinking excrements or residues that get mixed with a thick slimy liquid. Subsequently, the palm tree falls down during 6-12 months. (iii) Pupal stage (cocoon): The pupa (Figure 3.C), which has an average length of $6 \mathrm{~cm}$ and width of $3 \mathrm{~cm}$, prefers its cocoon to be surrounded by high humidity to prevent drying out and death. The cocoon was commonly found inside the trunks or inside the leafstalk of the infested Date Palms. (iv) Adult weevil: The ridden brown adult insect or weevil (Figure 3.D) is large and has a total length up to 42 $\mathrm{mm}$.

\section{The magnitude of infested Date Palms}

The number of infested Date Palms increased year by year. Figure 4 show that the magnitude of infested Date Palms in the Gaza Strip increased from 2011 to 2014. In 2015, there was a decline of the infested Date Palms.

\section{Trapping of the RPW}

With regard to the trapping of the RPW, figure 5 shows that there is a direct proportional concerning the number of traps employed and the number of adult weevils caught (2012-2015). It is worth mentioning that the trapping of the RPW mostly occurred in the southern Gaza Strip. The young Date Palms (Hayani, Barhee or other cultivars) that have been planted during the last 10-15 years are very attractive to and easily infested by the RPW as they have a lot of offshoots and their leaf bases are not dry enough to prevent egg lying of the adult insects. The aim of the deployment of traps, one trap per 50 trees in 2012 till 2015 is given to indicate the source of infection and its distribution as well as to combat the insect.

\section{Control levels of the RPW}

The most successful ways of control and management of the RPW in the Gaza Strip were represented by the application of IPM program. The IPM includes vital steps such as the regular monitoring of Date Palms, quick treatment of cuts and infections, early detection and treatment of infested trees, trapping of adult weevils, eradication of infested plants, proper pruning of fronds in addition to the conduction of good training programs targeting both farmers and agricultural officials. The following control levels were tracked in the Gaza Strip:

\section{Regulation level}

It includes enacted laws and decisions by the responsible authorities to protect Date Palms from pest infestation and to prevent the spread within the borders of Gaza Strip. When the first infested palms were discovered in 2011, the MOA has enacted a law that established the RPW as a quarantine pest having potential economic importance, and as a result, the transport of Date Palm trees and offshoots has been prohibited. This point is crucial from the beginning because no success was achieved in controlling the RPW pest. Both farmers and responsible associations have been informed not to transport such trees till the RPW is to be eradicated.

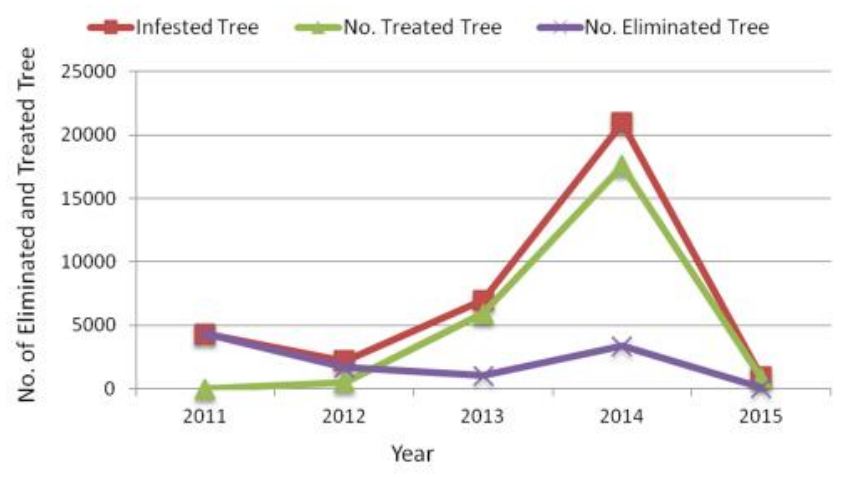

Figure 4. The magnitude of infested Date Palms in the Gaza Strip (2011-2015) (MOA 2016)

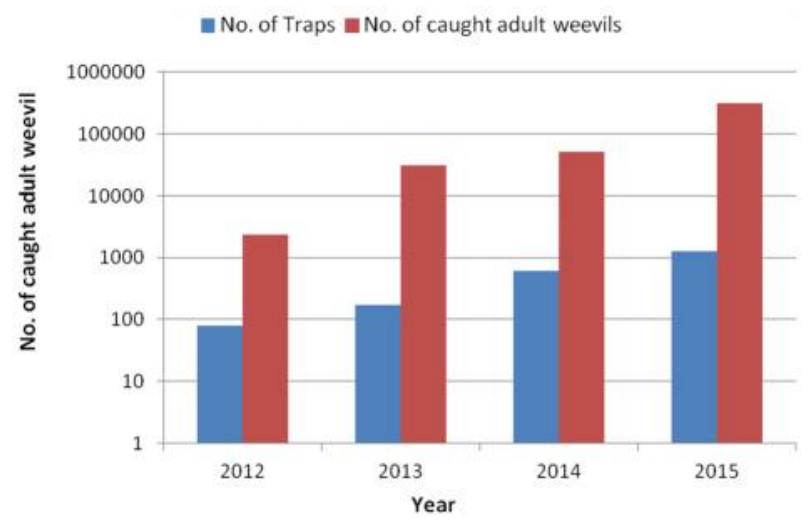

Figure 5. The number of traps and caught weevils (MOA 2016) 

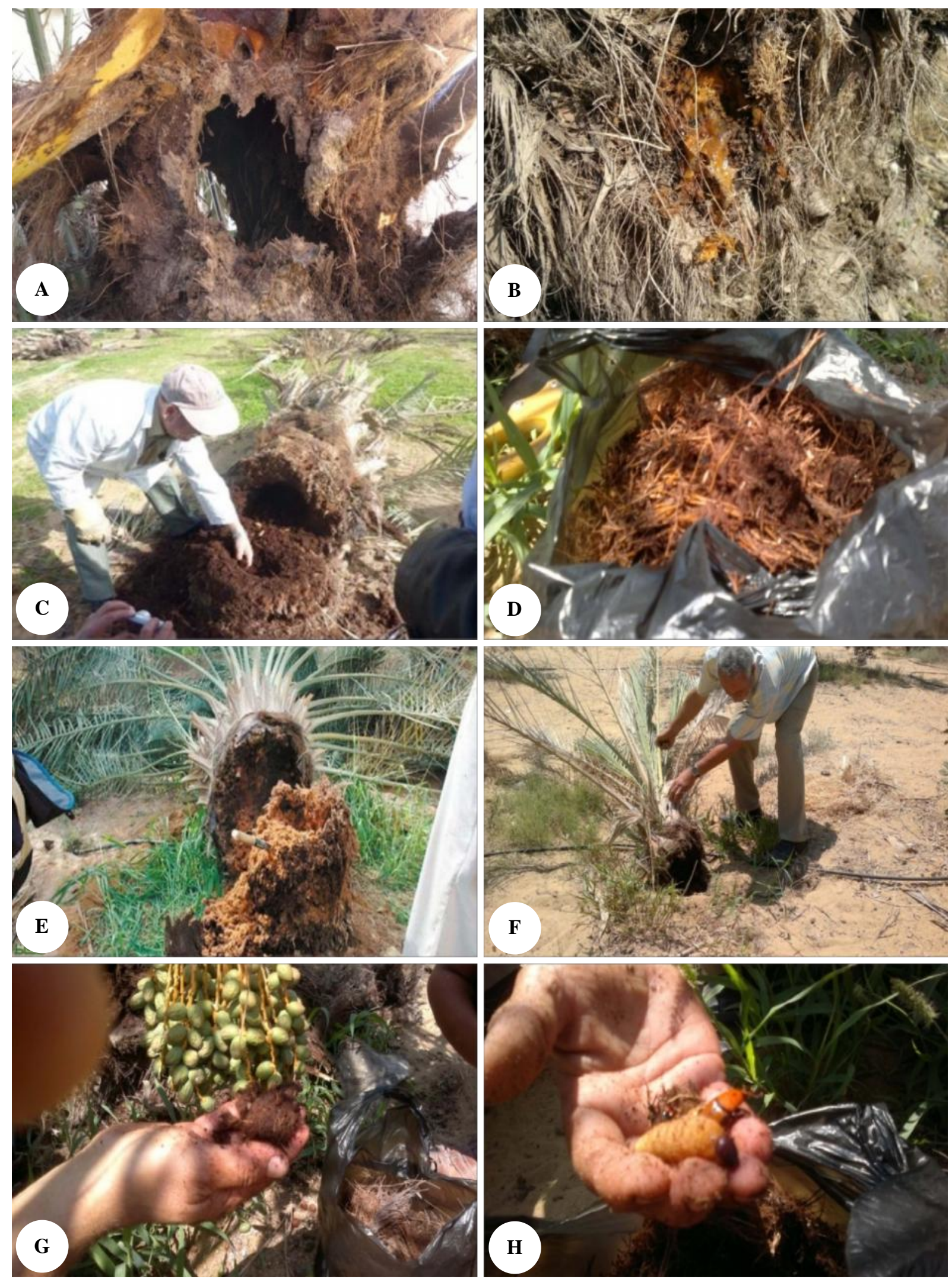

Figure 2. Symptoms of infection with RPW: A. Presence of tunnels on the trunk, B. Oozing out of thick brown fluid from the tunnels, C-D. Presence of chewed plant tissues, E. Breaking of the trunk, F. Drying and/or death of offshoots, G. Drying of fruits, H. Presence of any of RPW phases. 

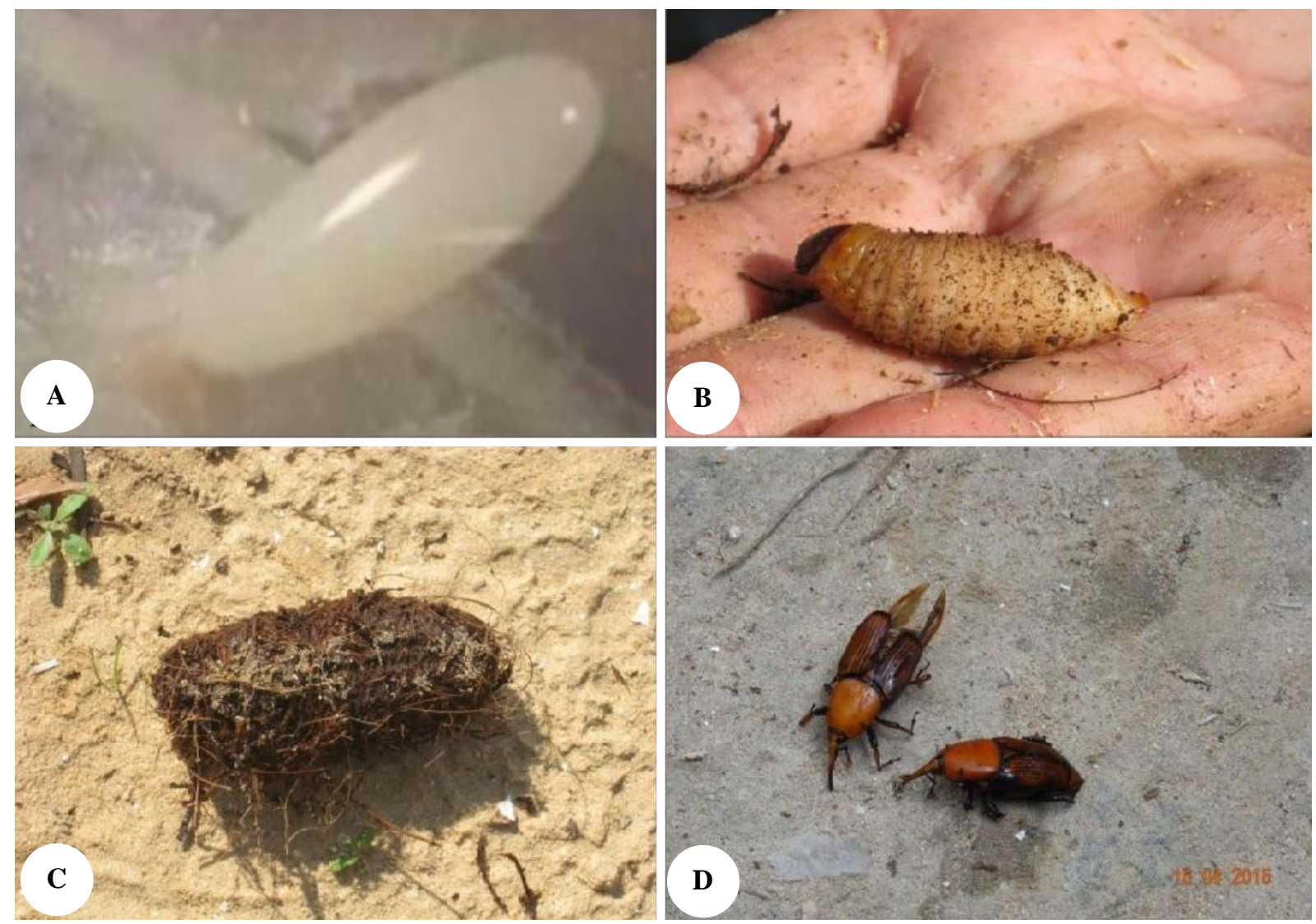

Figure 3. Life cycle of the Red Palm Weevil: A. Egg stage, B. Larval stage, C. Pupal stage, D. Adult weevil

\section{Organization level}

Once the infestation by the RPW occurred in 2011, the MOA cooperated with the FAO and other associations including ASDPD, PNAPD, ICRC and Palestinian NonGovernmental Organizations Network (PNGOs) to establish the RPW Committee in order to control and combat the RPW pest. A team from MOA has realized an important work of detection, sanitation, and monitoring of the RPW. The team distributed pesticides and other tools to farmers and brought a bulldozer to eliminate the infested Date Palms. In the Gaza Strip, farmers have been involved in the early detection and control process of the RPW pest. Many activities and interventions adopted and held by the related associations and institutions regarding the seriousness of the RPW pest. These included: (i) Workshops to train the local farmers on the suitable control methods of the RPW pest were organized by the RPW Committee (Figure 6). (ii) A total number of 1500 brochures prepared by FAO and ASDPD were edited and distributed by MOA. (iii) A technical booklet concerning the RPW was edited by ASDPD with the assistance of GEF/SGP. (iv) A leaflet concerning the RPW was prepared and distributed by the EHCRS.

\section{Technical level}

It was mandatory to judiciously mix various methods of control to successfully control the RPW in the Gaza Strip.
Such cultural, chemical, biological, mechanical, quarantine control techniques have been applied:

Agricultural control: The farming practices adopted by farmers play an important role in the health of Date Palms and the infestation levels. Local farmers applied on a scheduled basis various agricultural control methods such as the use the right irrigation, proper fertilization, cleaning and pruning of palms and their offshoots. Such operations can remove the potential sources of infestation by pests.

Mechanical control: This method depends on the use of manual or mechanical means to eliminate the insect. The most important means noticed in Date Palm orchards were: Removal of the infested or dead trees and the pruning products in neglected farms (Figure 7), the use of mud to close the holes of trunk resulted from offshoot removal, the cover of roots of small trees with soil to a height of $20 \mathrm{~cm}$ to prevent insect attack, and the burning of old fronds and infected offshoots to prevent the spread of infection to healthy trees. When severely damaged and dead palms are noticed, they were removed and disposed of properly. In this case, the palms are cut to smaller bits and treated with pesticide and then burned. In large scale removals, heavy machinery like bulldozers was used to transport the infested trees to a dumping site far from the infested farm to be completely burnt in order to kill any residual populations of the RPW. 
Biological control: In spite of its importance as an IPM technique, the biological control means have never been applied by the responsible authorities to combat the RPW in the Gaza Strip.

Behavioral control using the aggregation pheromone traps: The efficient and cheap aggregation pheromone traps (Figure 8) used in the Gaza Strip are either homemade or imported from abroad. They are commonly put one trap per 50 trees to attract the adult insects. The Earth and Human Center for Research and Study (EHCRS) experienced home-made traps with different colors; red, white, black and yellow. The preliminary results showed that the black traps were the most efficient in attracting the adult RPW.

Chemical control: This method depends on both preventive and therapeutic programs. The preventive control included the spraying or dusting of chemical pesticides such as Dursban, Rogor, and Confidor on the trunks and leaves of the intact trees (Figure 9). The therapeutic control included the spraying or dusting of pesticides on the trunks and leaves of the infected trees by using of injection devices and fumigation.

Injection: The injection is taken place through making three holes rising $20 \mathrm{~cm}$ from the place of infestation. Injection devices (Figure 10) are commonly used to inject the appropriate pesticides into the infected tree. Such an injection treatment may weaken the tree and allow other pests to invade the tree itself. Cotonion, Diazinon, Metasystox, Marshal, Sybrein, Dursban, Rogor, and Confidor are commonly used pesticides in this method.

Fumigation: This method is used in severe infections causing tunnels in the trunks. Fumigation tablets called Phostoxin have been applied against the RPW infestation (Figure 11). To fumigate the pest, three holes have to be drilled into the tree: one at the point of infestation, the second $20 \mathrm{~cm}$ above and the third $20 \mathrm{~cm}$ below the first hole. The part of the trunk that oozes is to be cleaned and then, the decaying tissues and grubs are to be removed as much as possible. One tablet of Phostoxin is usually placed in the drilled hole. Sealing with moistened clay is then followed in order to prevent the leak of evaporated gas resulting from Phostoxin.

\section{Discussion}

The RPW is considered one of the most destructive pests of the Date Palm trees all over the world. The findings of the current study revealed that the RPW is the main threat facing Date Palm cultivation and making considerable losses in the Gaza Strip, which represents a microscopic zone in the Middle East. The severity of the pest comes from the fact that it is the most common dangerous pest threatening the Date Palm sector in the Middle East. It is responsible for the death of a large number of Date Palms and consequent yield losses in the area as indicated by Vidyasagar et al. (2016).

The current survey revealed that the number of infested Date Palm trees is increasing year by year and causes severe losses to Gazan farmers. The absence of inspection and surveillance of the new offshoots entering the Gaza Strip through the earth tunnels connecting it with the
Egyptian Territories is a capital factor enhanced the occurrence of the pest locally. It is well known that the adult RPW has the ability to fly relatively long distances ( $1 \mathrm{~km}$ per day), and this may interpret the quick and widespread infestation among Date Palm trees coming from Egypt into the Gaza Strip in the recent years. In this context, FAO recommended the establishment of a buffer zone with the Egyptian borders to prevent the entry of adult weevils into Gaza Strip. This proposed recommendation relied on the capability of the adult RPW to fly for long distances as mentioned previously.

The life cycle of RPW is reported to vary chronologically depending on the environmental and geographical conditions (Al-Saqer and Hassan 2011). The larva stage is considered the main damaging stage because it bores into Date Palm trees, feeds on the succulent plant material and remains hidden through most of the life cycle. It is responsible for the most symptoms encountered and seen on the infested trees during the field visits conducted by the authors to Date Palm orchards. Similar symptoms were reported by Vidyasagar and Aldosari (2011), AlSaqer and Hassan (2011) and Faleiro et al. (2012) who confirmed more or less symptoms in the Date Palms infested by the RPW in various geographical areas.

The local control of the RPW depended on the application of IPM programs. IPM seeks to reduce chemical input through the inclusion of a range of methods which are environmentally compatible. Different approaches such as agricultural, chemical, behavioral, mechanical and quarantine control means are more or less applied in the Gaza Strip. Agricultural and mechanical controls are sometimes the commonest because of the nonavailability or high costs of chemical pesticides. Murphy and Briscoe (1999), Vidyasagar and Aldosari (2011), Aleid et al. (2015) and Dembilio and Jaques (2015) indicated that the concealed nature of the larvae of RPW requires effective methods for its management including the IPM strategy.

Despite its importance, the biological control methods are not applied in the Gaza Strip due to several reasons including the shortage or unavailability of qualified staff, specialized research, specialized equipment and funding sources. The political, military and socioeconomic circumstances of the Gaza Strip could not be ignored in this regard. The crucial benefit of biological control comes from its relative safety for human health and the environment, compared to widespread use of different pesticides. In Egypt, many researcher gained good results when they used different biological agent to control the RPW (Abbas et al. 2000; Abdullah 2009 and Abdel-Samad 2011). Locally, El-Hindi (2017) and El Kichaoui et al. (2017) achieved good laboratory results regarding the effectiveness of the fungi Metarhizium anisopliae and Beauveria bassiana against the RPW in the Gaza Strip. Finally, the study recommends the cooperation of different parties and authorities to adopt appropriate policies to eliminate the RPW and to support farmers with necessary control means and modern equipment to combat this painful pest. 


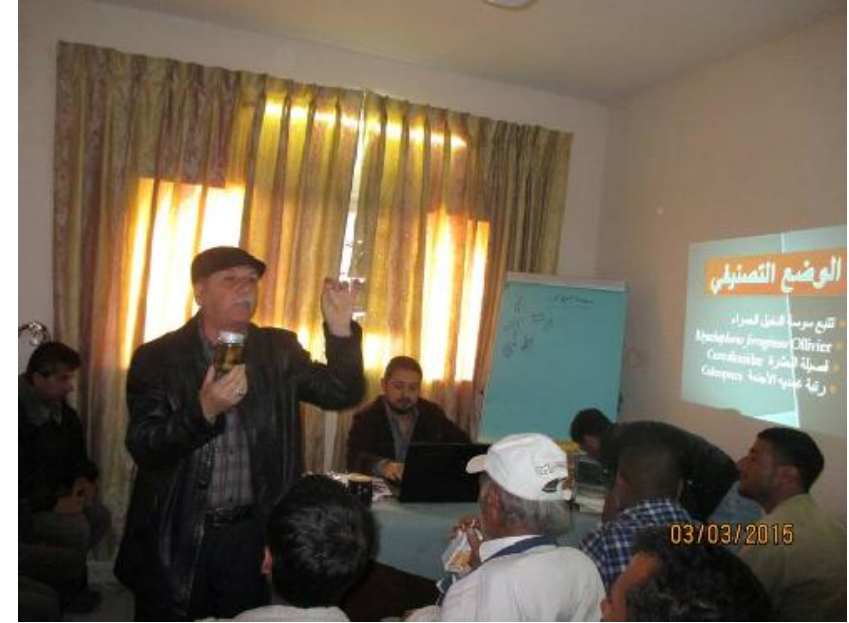

Figure 6. Organization of workshops to train the local farmers on the suitable control methods of the RPW pest

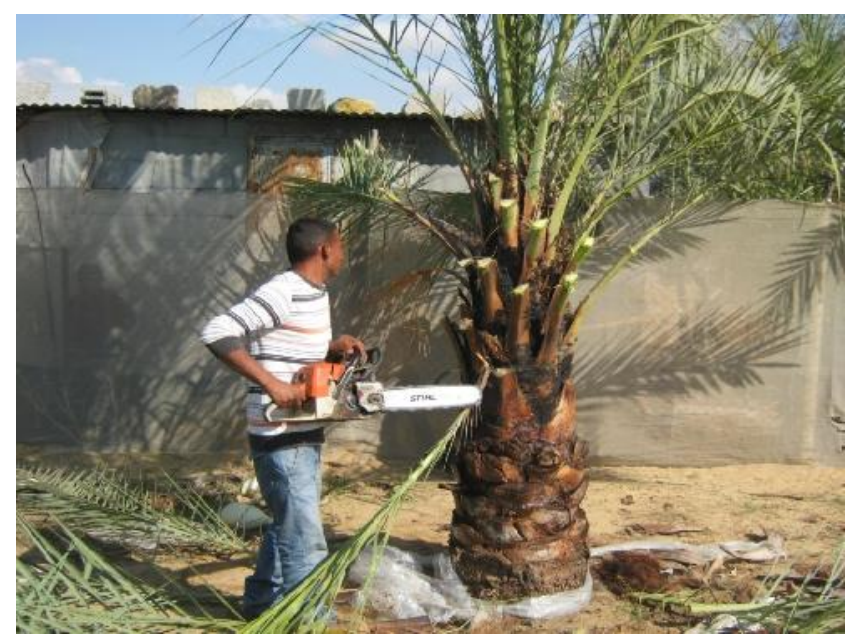

Figure 7. Removal of Date Palms infected by RPW

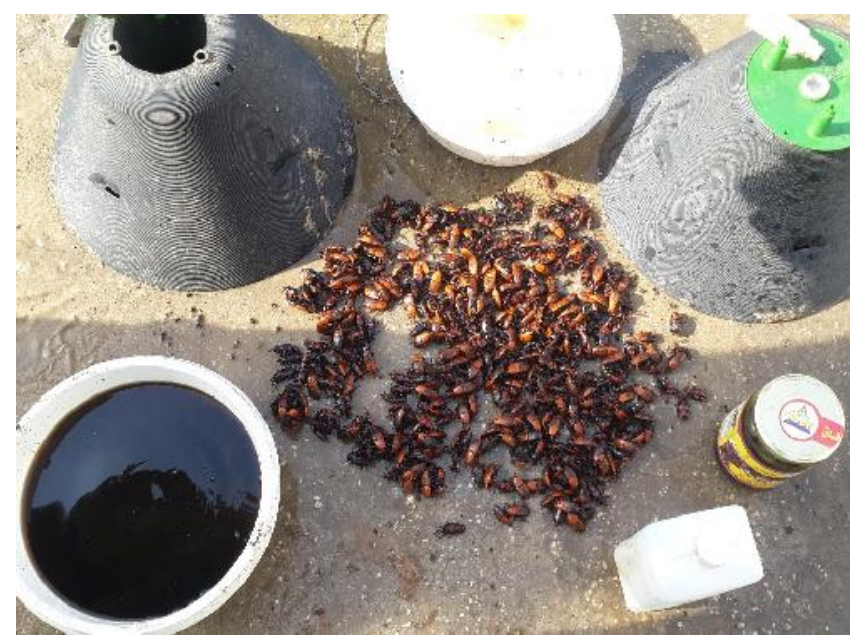

Figure 8. The components of RPW traps

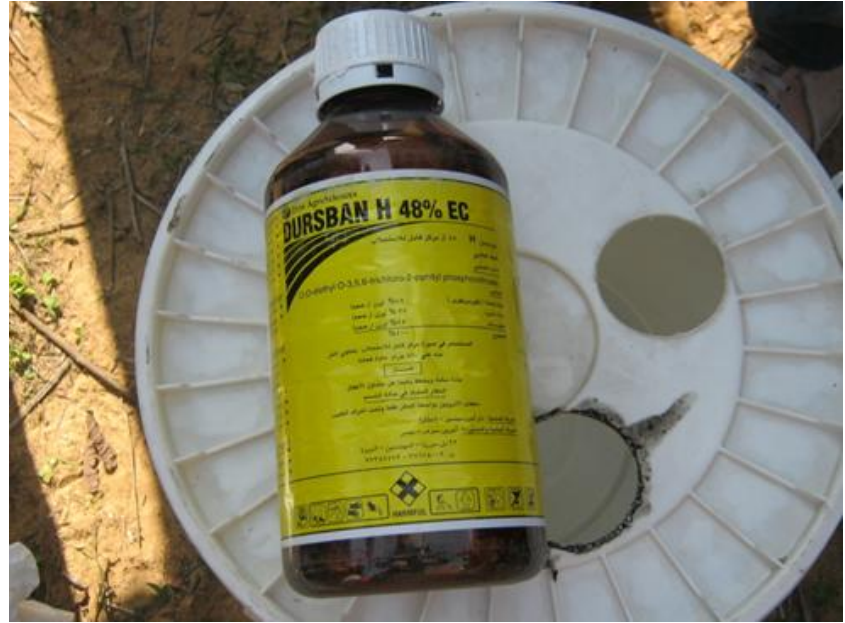

Figure 9. The Dursban pesticide is commonly used to combat the RPW pest

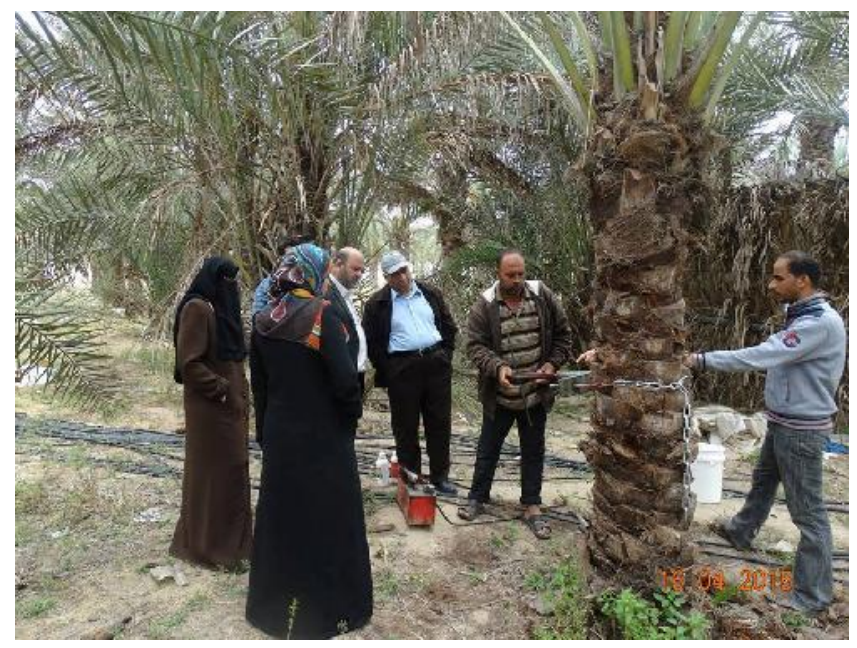

Figure 10. Injection device used to inject pesticides inside Date Palms infested by RPW

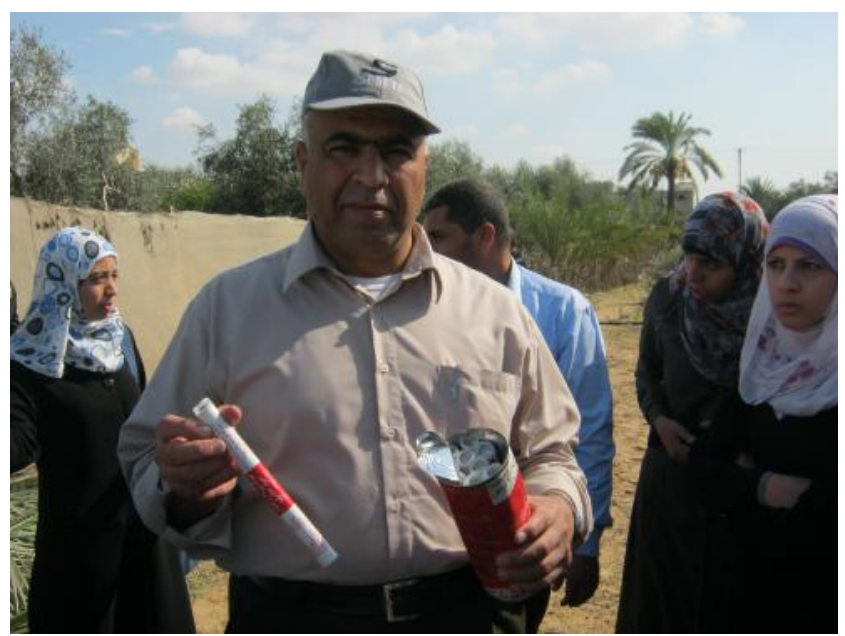

Figure 11. Phostoxin fumigation tablets applied on Date Palms infested by RPW 


\section{ACKNOWLEDGEMENTS}

We would like to acknowledge and extend our gratitude to the staff of the Ministry of Agriculture (MOA), Earth and Human Center for Research and Study (EHCRS), Palestinian Al-Nakheel Association for Progress and Development (PNAPD), Al-Ahlyah Association for the Development of Date Palm (ASDPD), Gazan farmers, owners of Date Palm orchards and normal people who spared no effort in supporting and enriching the current study with the information, critical discussions, and comments throughout the succeeding stages of the current study.

\section{REFERENCES}

Abbas MST, Hanounik SB, Mousa SA, Al-Bagham SH. 2000. Soi application of entomopathogenic nematodes as a new approach for controlling Rhynchophorus ferrugineus on date palm. Intl J Nematol 10: 215-218.

Abdel-Samad SSM, Mahmoud BA, Abbas MST. 2011. Evaluation of the fungus, Beauveria bassiana (Bals.) Vuill as a bio-control agent against the red palm weevil, Rhynchophorus ferrugineus (Oliv.) (Coleoptera: Curculionidae). Egypt. J Biol Pest Control 21: 125-129.

Abdel-Wahed MS, Abdel-Megeed M I, El-Zemaity MS, Redha AA. 2014 Ecological aspects and pattern of red palm weevil infestation in date palm orchards. In fifth international Date Palm conference. 16-18, March, Abu Dabi, United Arab Emirate.

Abd Rabou AN and Radwan ES. 2017. The current status of the date palm (Phoenix dactylifera) and its uses in the Gaza Strip, Palestine. Biodiversitas 18 (3): 1047-1061.

Abdullah MAR. 2009. Biological control of the Red Palm Weevil, Rhynchophorus ferrugineus (Olivier) (Coleoptera: Curculionidae) by the parasitoid mite, Rhynchopolipus rhynchophori (Ewing) (Acarina: Podapolipidae). J Egypt Soc Parasitol 39: 679-686.

Abe F, Hata K, Sone K. 2009. Life history of the red palm weevil, Rhynchophorus ferrugineus (Coleoptera: Dryophtoridae), in Southern Japan. Florida Entomol 92 (3): 421-425.

Abraham VA, Shuaibi MA, Faleiro JR, Abozuhairah RA, Vidyasagar PS. 1998. An integrated management approach for red palm weevil Rhynchophorus ferrugineus (Olivier), a key pest of date palm in the Middle East. J Agric Mar Sci 3 (1): 77-83.

Abu-Qaoud H. 2015. Date Palm Status and Perspective in Palestine. In: Al-Khayri JM, Jain SM, Johnson DV (eds.). Date Palm Genetic Resources and Utilization. Africa and the Americas 2: 423-439, Springer, Doordecht, the Nederland.

Al-Agha BA. 2016. Palm cultivation in Gaza governorates, A study in agricultural geography. [Thesis]. Islamic University of Gaza, Palestine.

Al-Dosary NMN, Al-Dobai S, Faleiro JR. 2016. Review on the management of red palm weevil Rhynchophorus ferrugineus (Olivier) in date palm Phoenix dactylifera L. Emirates J Food Agric 28 (1): 34 44.

Aleid SM, Al-Khayri JM, Al-Bahrany AM. 2015. Date Palm Status and Perspective in Saudi Arabia. In: Al-Khayri JM, Jain SM, Johnson DV (eds.). Date Palm Genetic Resources and Utilization. Africa and the Americas 2: 49-95, Springer, Doordecht, the Nederland.

Al-Jaghoub N, Al-Laham S, Barhum H. 2003. The Date Palm tree: Taken Care of it and the Most Important Pests and Diseases that Afflect it. Palestinian Ministry of Agriculture, Ramallah, Palestine. [Arabic]

Al-Saqer SM, Hassan GM. 2011. Red palm weevil (Rynchophorus ferrugineous, Olivier) recognition by image processing techniques. Amer J Agric Biol Sci 6 (3): 365-376.

ASDPD [Al-Ahlyah Association for the Development of Date Palm]. 2012. Guideline on the Red Palm Weevil: Symptoms and Method of Control. Deir Al-Balah, Palestine.
Azam KM, Razvi SA, Al-Mahmuli I. 2001. Survey of red palm weevil, Rhynchophorus ferrugineus (Oliver) infestation in date palm in Oman. In: Second International Conference on Date Palms, Al-Ain, Egypt.

Bertone C, Michalak S, Roda A. 2010. New pest response guidelines: Red palm weevil. Emergency and Domestic Programs, USDA-APHIS.

Chao CT, Krueger RR. 2007. The date palm (Phoenix dactylifera L.): Overview of biology, uses, and cultivation. HortScience 42 (5): 10771082

Dembilio Ó, Jaques JA. 2015. Biology and Management of Red Palm Weevil. In. Wakil W, Faleiro JR, Miller TA (eds.), Sustainable Pest Management in Date Palm:Current Status and Emerging Challenges. Springer, Dordrecht.

EHCRS [Earth and Human Center for Research and Study]. 2011. The Red Palm Weevil, Farmers Capacity Enhancement to Fight Red Palm Weevil (RPW) in Gaza Strip. Earth and Human Center for Research and Study, Palestine.

El-Hindi MW. 2017. Isolation, Molecular Identification and under Lab Evaluation of the Entomopathogenic Fungi $M$. anisopliae and $B$. bassiana against the Red Palm Weevil R. ferrugineus in Gaza Strip. [Thesis]. The Islamic University of Gaza, Palestine.

El Kichaoui AY, Abu Asaker BA, El-Hindi MW. 2017. Isolation, Molecular Identification and under Lab Evaluation of the Entomopathogenic Fungi $M$. anisopliae and $B$. bassiana against the Red Palm Weevil R. ferrugineus in Gaza Strip. Adv Microbiol 7: 109124

Faleiro JR, Ben Abdallah A, El Bellaj M, Al-Ajlan AM, Oihabi A. 2012. Threat of Red Palm Weevil, Rhynchophorus ferrugineus (Olivier) to date plantations of the Maghreb region in North Africa. Arab J Plant Protect 30: 274-280.

Ferry M, Gomez S. 2002. The red palm weevil in the Mediterranean area. Palms 46: 172-178.

Hoddle MS, Hoddle CD, Faleiro JR, El-Shafie HAF, Jeske DR, Sallam AA. 2015. How far can the red palm weevil (Coleoptera: Curculionidae) fly? Computerized flight mill studies with fieldcaptured weevils. J Econ Entomol 108 (6): 2599-2609.

Kaakeh W, El-Ezaby F, Aboul-Nour MM, Khamis AA. 2001. Management of the red palm weevil, Rhynchophorus ferrugineus (Olivier), by a pheromone/food-based trapping system. In Second International Conference on Date Palms, Al-Ain, Egypt.

Mazza G, Francardi V, Simoni S, Benvenuti C, Cervo R, Faleiro E, Longo S, Nannelli R, Tarasco E. 2014. An overview on the natural enemies of Rhynchophorus palm weevils, with focus on $R$. ferrugineus. Biol Control 77: 83-92.

MOA. 2011. Red Palm Weevil. Ministry of Agriculture, Gaza, Palestine.

MOA. 2012. Red Palm Weevil, Agricultural Media Version, Public Administration Agricultural Plant Protection and Quarantine. Ministry of Agriculture, Gaza, Palestine.

MOA. 2016. Red Palm Weevil. Ministry of Agriculture, Gaza, Palestine.

Murphy S, Briscoe B. 1999. The red palm weevil as an alien invasive: biology and the prospects for biological control as a component of IPM. Biocontrol News Info 20 (1): 35-46.

Nisson N, Hodel D, Hoddle MS. 2010. Red Palm Weevil, Rhynchophorus ferrugineus (Olivier). Center for Invasive Species Research, University of California, Los Angeles.

PCBS [Palestinian Central Bureau of Statistics Agricultural Statistical Data]. 2016. Palestine Statistical Yearbook. Ramallah, Palestine. http//www.pcbs.gov.ps/ at 5/2/2017.

Radwan ES. 2017. The Current Status of the Date Palm Tree (Phoenix dactylifera L.) and its Uses in the Gaza Strip, Palestine. [Thesis]. Islamic University of Gaza, Palestine.

UNEP (United Nations Environment Program). 2003. Desk Study on the Environment in the Occupied Palestinian Territories. Nairobi, Kenya.

Vidyasagar PS, Aldosari SA. 2011. IPM of Red Palm Weevil. Chair of Date Palm Research (CDPR), Plant Protection Department, College of Food and Agricultural Sciences, King Saud University, Riyadh, Saudi Arabia.

Vidyasagar PS, Aldosari SA, Sultan EM, Al Saihati A, Khan RM. 2016. Efficiency of optimal pheromone trap density in management of red palm weevil, Rhynchophorus ferrugineus Olivier. African J Agric Res 11 (12): 1071-1078 